UDK 633.11:631.453:547.992

DOI: 10.31651/2076-5835-2018-1-2020-1-42-52

Litvin Valentina Anatoliivna

Ph.D., Associate Professor

Bohdan Khmelnitsky National University Department of Chemistry and Nanomaterial Science

litvin_valentina@ukr.net

ORCID 0000-0003-1236-6344

Deriy Serhiy Ivanovych

Ph.D., Associate Professor

Bohdan Khmelnitsky National University Department of Biology, Ecology and Agrotechnology deriy_s i@ukr.net ORCID 0000-0003-0926-1218 Plakhotniuk Liana Mykolaivna Biology teacher Cherkasy specialized school I-III degree No. 33 named after V. Symonenko plm10111982@gmail.com

Njoh Roger Abi

Ph.D. Student

Near East University Department of Toxicology rogersco90@yahoo.com ORCID 0000-0003-3812-2444

\title{
EFFECTS OF HUMIC SUBSTANCES ON SEED GERMINATION OF WHEAT UNDER THE INFLUENCE OF HEAVY METAL
}

Introduction. The rapid development of industry in recent decades has caused global pollution, including heavy metals. Of particular danger is the accumulation of heavy metals in plants widely cultivated in crop production practices, such as wheat. Among growth-promoting and remedying drugs, compounds of natural origin - humic substances - deserve special attention. Currently, around the world there is an increased interest in humic substances, the technologies for their production are being improved, and the raw material base is expanding, in which all new types of raw materials are involved. Of particular interest are synthetic humic substances, which are obtained from low molecular weight phenolic precursors. Strict control of the synthesis conditions allows obtaining a product with standardized properties, which is one of the advantages over natural humic substances. In addition, it is assumed that the nature of the low molecular weight phenolic precursor affects the biological activity of the final product.

Purpose. The aim of our study was to study the effect of humic substances of various origins (a complex preparation of natural humic substances and synthetic fulvic acids from catechol) on the germination and morphological characteristics of wheat under the influence of heavy metals $\left(\mathrm{Cu}^{2+}\right)$.

Methods. During the study, laboratory, accounting, analytical and mathematical-statistical methods were used.

Result. A comparative study of the effect of a complex preparation of natural humic substances and synthetic fulvic acids from catechol on the germination of wheat seeds shows their stimulating effect compared to the control by $11.2 \%$ and $8.2 \%$, respectively. The presence in the nutrient solution of $\mathrm{Cu}^{2+}$ ions at the levels of 0.5, 1 and 5 MPC contributed to the increase of germination energy and germination of seeds in all experiments. The types of humic substances investigated intensify the growth processes in green shoots of wheat. Compared to the control, their 
length increased by $18.9-35.1 \%$. In addition, these substances inhibit the negative effects of $\mathrm{Cu}^{2+}$ ions even at the level of 5 MPC. Aqueous solutions of $\mathrm{Cu}^{2+}$ ions have been found to stimulate the formation of primary roots in wheat. At the same time, ions of this heavy metal have a negative effect on root growth, reducing their length by 7.5 times compared to the control. The total length of all roots in wheat plants under the action of different types of humic substances exceeded the control values by 42 - 50\%. At the same time, these substances significantly improved root growth when $\mathrm{Cu}^{2+}$ ions were present in the nutrient solution. The presence of $\mathrm{Cu}^{2+}$ ions in the solution adversely affected the crude mass of green shoots and roots in the studied wheat plants. However, humic substances improved these indicators compared to the control by $26.8-43.3 \%$, which indicates their detoxifying effect.

Conclusion. Thus, the treatment of wheat seeds with the studied preparations of natural humic substances and synthetic fulvic acids from catechol activates biological and physiological processes in the seed, thereby affecting the vital activity of the plant at the initial stage of development, affects the formation of additional primary roots and the growth of wheat seedlings. The studied preparations have a positive effect on the accumulation of fresh mass of wheat seedlings, and allow to obtain friendly and uniform seedlings. In addition, under conditions of soil pollution with $\mathrm{Cu}^{2+}$ ions, various types of humic preparations exhibit phytoprotective properties.

Key words: humic substances, synthetic fulvic acids, heavy metals, wheat, germination energy, morphological characteristics.

The problem setting. Increasing anthropogenic impact on the environment leads to increased accumulation of highly toxic heavy metals in soil, water, living organisms. Heavy metals include more than 40 elements, the atomic mass of which exceeds 50 amu [1]. Many of these elements are necessary for plant life, but at high concentrations they cause a complex of negative changes leading to metabolic disturbances, inhibition of photosynthesis, respiration, inhibition of growth processes, and plant death.

Copper - one of the main pollutants in contaminated areas, is the most toxic heavy metal. The main reasons for the increase in the copper content in the environment are the widespread use of copper-containing pesticides and the accumulation of industrial waste. In low concentrations, copper is an essential microelement for plants, which is part of the most important redox enzymes involved in photosynthesis, respiration, and restoration of nitrogen fixation [2]. Excessive doses of copper cause a change in the permeability of cell membranes, impaired electron transport in electron transport chains, inactivation of enzymes, inhibition of root and shoot growth, induce oxidative stress in plant cells, disrupt the normal development of the root system $[2,3]$. Moreover, the range of copper concentrations that do not have a pronounced toxic effect on plants is very narrow.

A small number of studies have shown that humic substances (HSs) reduce the toxicity of heavy metals [4, 5]. The detoxifying effect of humic substances at high concentrations of heavy metals in the environment is due to the formation of non-toxic complexes of humic substances with metals and a decrease in their availability to plants.

Humic substances are a specific group of macromolecular compounds that are formed from organic residues when oxygen is difficult to access. Their content in sea waters is $0.1-$ $3 \mathrm{mg} / \mathrm{L}$, in river waters - $20 \mathrm{mg} / \mathrm{l}$, in marshes - up to $200 \mathrm{mg} / 1$, in soils - $1-12 \%$ [6]. Humic substances are divided into three types according to their solubility in acids and alkalis: fulvic acids (soluble at any $\mathrm{pH}$ ), humic acids (insoluble at $\mathrm{pH}$ less than 2) and humin (insoluble residue) [7].

According to the chemical structure, HSs are classified as high molecular weight aromatic hydroxycarboxylic acids [8]. The basis of their structure is condensed systems, including alicyclic and aromatic rings, side chains of varying degrees of branching, and hydrophilic functional groups in the nucleus and inside chains. Depending on the source and extraction method, they have certain differences in elemental composition, degree of condensation of molecules, number of functional groups, molecular weight, ratio of hydrophobic and hydrophilic fragments [9]. The multifunctional nature of HSs and their salts 
determine their widespread use as biologically active substances [10, 11]. Of particular interest are synthetic humic substances obtained under strictly controlled conditions from low molecular weight phenolic precursors, which determines their reproducible properties [1214]. If the biostimulating properties of natural humic substances are reported in the literature [15-17], such information is not available for synthetic humic substances. In addition, the nature of the low molecular weight precursor may affect the biostimulating properties of the final product. In this connection, a comparative study of the biological activity of synthetic and natural humic substances is of interest.

The aim was to study the effect of natural humic substances (as part of commercial complex preparation) and synthetic fulvic acids from catechol on the growth and development of wheat and the ability to bind heavy metals.

\section{The research methodology and organization}

To determine the germination energy and seed germination of wheat, seeds were germinated in a thermostat at $25^{\circ} \mathrm{C}$ in Petri dishes on filter paper moistened with the solutions under study. The 50 grains were used in each experiment and performed in three replicates. In the experimental variants used:

1) solutions of synthetic fulvic acids (SFA) obtained by oxidation of catechol [18]; $\mathrm{SFA}+0.5 \mathrm{MPC} \mathrm{Cu}^{2+} ; \mathrm{SFA}+1 \mathrm{MPC} \mathrm{Cu}^{2+} ; \mathrm{SFA}+5 \mathrm{MPC} \mathrm{Cu}^{2+}$

2) complex potassium humate $(\mathrm{CPH})$ produced in the Freya-Agro research and production complex, to which $\mathrm{CuSO}_{4}$ was added - $\mathrm{CPH}+0.5 \mathrm{MPC}$ (maximum permissible concentration) $\mathrm{Cu}^{2+}, \mathrm{CPH}+1 \mathrm{MPC} \mathrm{Cu}{ }^{2+}, \mathrm{CPH}+5 \mathrm{MPC} \mathrm{Cu}^{2+}$;

3 ) distilled water (control) and aqueous solutions with a corresponding content of $\mathrm{Cu}^{2+}$ ions: $\mathrm{H}_{2} \mathrm{O}+0.5 \mathrm{MPC} \mathrm{Cu}^{2+}, \mathrm{H}_{2} \mathrm{O}+1 \mathrm{MPC} \mathrm{Cu}^{2+}, \mathrm{H}_{2} \mathrm{O}+5 \mathrm{MPC} \mathrm{Cu}^{2+}$.

The seed germination energy was determined on the third day, and the germination on the seventh day. Germination energy is the friendliness of seed germination after 3 days of germination expressed as a percentage. Seed germination is the number of normally germinated seeds in the sample in percentage [19].

During the first counting, normally sprouted seeds, as well as seeds with pronounced signs of anomalies and rotten, are separately evaluated and taken into account. The last two groups are removed, and normally sprouted - if necessary. Normal seedlings include those in which the most important structures (roots, hypocotyl, epicotyl, bud, cotyledons, coleoptiles) are well and proportionally developed, whole, healthy, as well as with minor defects in those structures that do not affect the normal development of the seedling. These include normally developed seedlings with signs of superficial infection acquired from neighboring diseased seeds. In crops, the seeds of which sprout several germinal roots (cereal crops) in normally sprouted kernels, those that have at least two normally developed roots, large grain lengths and a sprout of no less than half its length [20].

Abnormal seedlings include those that can develop into full-fledged plants even under favorable conditions. These include: seedlings in which no structure is missing or severely damaged, makes it impossible for them to further develop proportionally; underdeveloped sprouts due to physiological disorders, as well as seedlings with deformed structures; decayed seedlings [20].

In the second part of the experiment, to determine some morphometric parameters of the vegetative organs of wheat under the influence of the test substances, the selected seeds were grown on rolls of filter paper soaked in appropriate solutions, 50 pieces in three replicates. $55 \mathrm{~cm} \mathrm{x} 10 \mathrm{~cm}( \pm 0.5 \mathrm{~cm})$ filter paper strips were used for each sample. The seeds were laid out in a single line with an interval of $3 \mathrm{~cm}$ at a distance of $4 \mathrm{~cm}$ from the top and side edges of the paper strip. The seeds were seeded with the embryos down. The rolls were placed vertically in vessels of 0.5 liters and filled with $80 \mathrm{ml}$ of test solutions. In the process 
of germination of seeds, the filter papers were not allowed to dry. Every 2-3 days the same amount of solution was added to the vessels. Room temperature fluctuated from 20 to $25^{\circ} \mathrm{C}$. The duration of the experiment is 20 days. After the end of the experiment, the rolls were removed from the vessel, unwound, carefully separated the seedlings of wheat and measured the length of green shoots, the length of the roots, the number of additional roots, the total length of the root system. Along with this weighed separately the green shoots and roots and determined their crude mass. The obtained plant material was dried at $100{ }^{\circ} \mathrm{C}$ to constant weight in a thermostat for further studies.

\section{The results and their discussion}

At a young age (the period of germination and sprouting), plants are most sensitive to the action of heavy metal salts. Their influence depends on both the level of toxicity of a metal and its concentration in a nutrient solution [1,3]. We studied (the average of three replicates) the index of seed germination energy and its laboratory germination, after soaking in solutions of $\mathrm{CuSO}_{4}$ and combinations of $\mathrm{CuSO}_{4}$ with solutions of humic substances. In control, the germination energy and germination of seeds were $85.1 \%$ and $88.2 \%$, respectively. In the variants $\mathrm{H}_{2} \mathrm{O}+0.5 \mathrm{MPC} \mathrm{Cu}{ }^{2+}, \mathrm{H}_{2} \mathrm{O}+1 \mathrm{MPC} \mathrm{Cu}^{2+}, \mathrm{H}_{2} \mathrm{O}+5 \mathrm{MPC} \mathrm{Cu}^{2+}$ the excess over control was from $4.3 \%$ to $6.2 \%$.

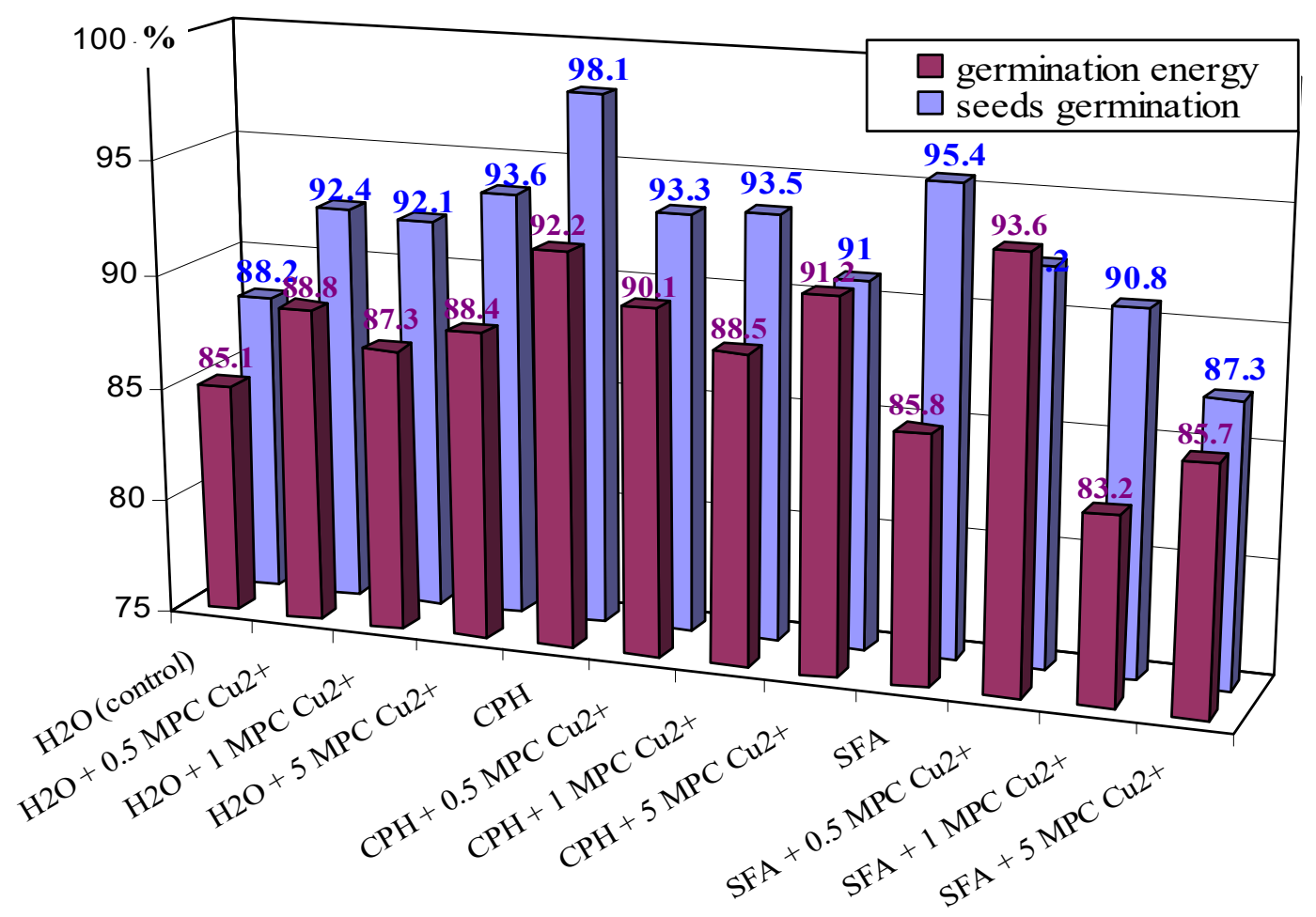

Fig. 1. Influence of humic substances and $\mathrm{CuSO}_{4}$ on germination energy and germination of wheat seeds.

Germination of seeds in aqueous solutions of $\mathrm{CPH}$ and SFA increased seed germination compared to control by $11.2 \%$ and $8.2 \%$, respectively. In the $\mathrm{CPH}+0.5 \mathrm{MPC}$ $\mathrm{Cu}^{2+}, \mathrm{CPH}+1 \mathrm{MPC} \mathrm{Cu}{ }^{2+}, \mathrm{CPH}+5 \mathrm{MPC} \mathrm{Cu}^{2+}$ variants, the germination was also higher than in the control, but compared with the $\mathrm{CPH}$ variant, the addition of copper sulfate slightly affected this indicator. In particular, in the $\mathrm{CPH}+5 \mathrm{MPC} \mathrm{Cu}^{2+}$ variant, the germination rate was $7.3 \%$. In the variants with synthetic fulvic acids: SFA $+0.5 \mathrm{MPC} \mathrm{Cu}^{2+}$, SFA $+1 \mathrm{MPC}$ 
$\mathrm{Cu}^{2+}, \mathrm{SFA}+5 \mathrm{MPC} \mathrm{Cu}^{2+}$, the germination rate was also $2-5 \%$ higher than in the control, but less than in the variant with SFA (Fig. 1). Thus, the presence in the nutrient solution of copper sulfate at the level of $0.5,1$ and 5 MPC stimulates the germination energy and germination of wheat seeds. One of the important and integral indicators of the level of plant vital activity is their growth, as well as some metric and meristic indicators of leaves, roots, shoots, inflorescences and fruits. In the course of the experimental studies, we obtained very interesting results on the growth of green shoots of wheat under the influence of humic substances and heavy metal ions - copper.

So, when in the control the length of green shoots was $14.57 \pm 0.56 \mathrm{~cm}$, then in the $\mathrm{CPH}$ variants $16.81 \pm 0.62 \mathrm{~cm}$ and in the SFA version $15.76 \pm 0.38 \mathrm{~cm}$. That is, the excess over the control was $15.4 \%$ and $8.2 \%$, respectively. The growth of wheat seedlings on a nutrient medium with the addition of copper(II) sulfate was significantly worse than in the control. Especially significant inhibition of shoot growth was observed in the $\mathrm{H}_{2} \mathrm{O}+5 \mathrm{MPC}$ $\mathrm{Cu}^{2+}$ variant. The decrease compared with the control was $14 \%$ (differences are statistically significant with a probability of 0.95 ). But the growth of green shoots on a nutrient medium, which included copper(II) sulfate (at the levels of 0.5, 1 and 5 MPC) together with humic substances has its own characteristics. In particular, $\mathrm{CPH}$ and SFA reduced the negative effect of $\mathrm{Cu}^{2+}$ ions on the growth processes in wheat plants. This is especially noticeable in cases where copper ions were at the level of 0.5 and 1 MPC. Synthetic fulvic acids increased the length of green shoots by $18.9-20.6 \%$, and complex potassium humate by $32.3-35.1 \%$. Even in the cases where copper ions were at the level of 5 MPC, an improvement in the growth processes was observed due to the presence of SFA and CPH in solutions (Fig. 2).

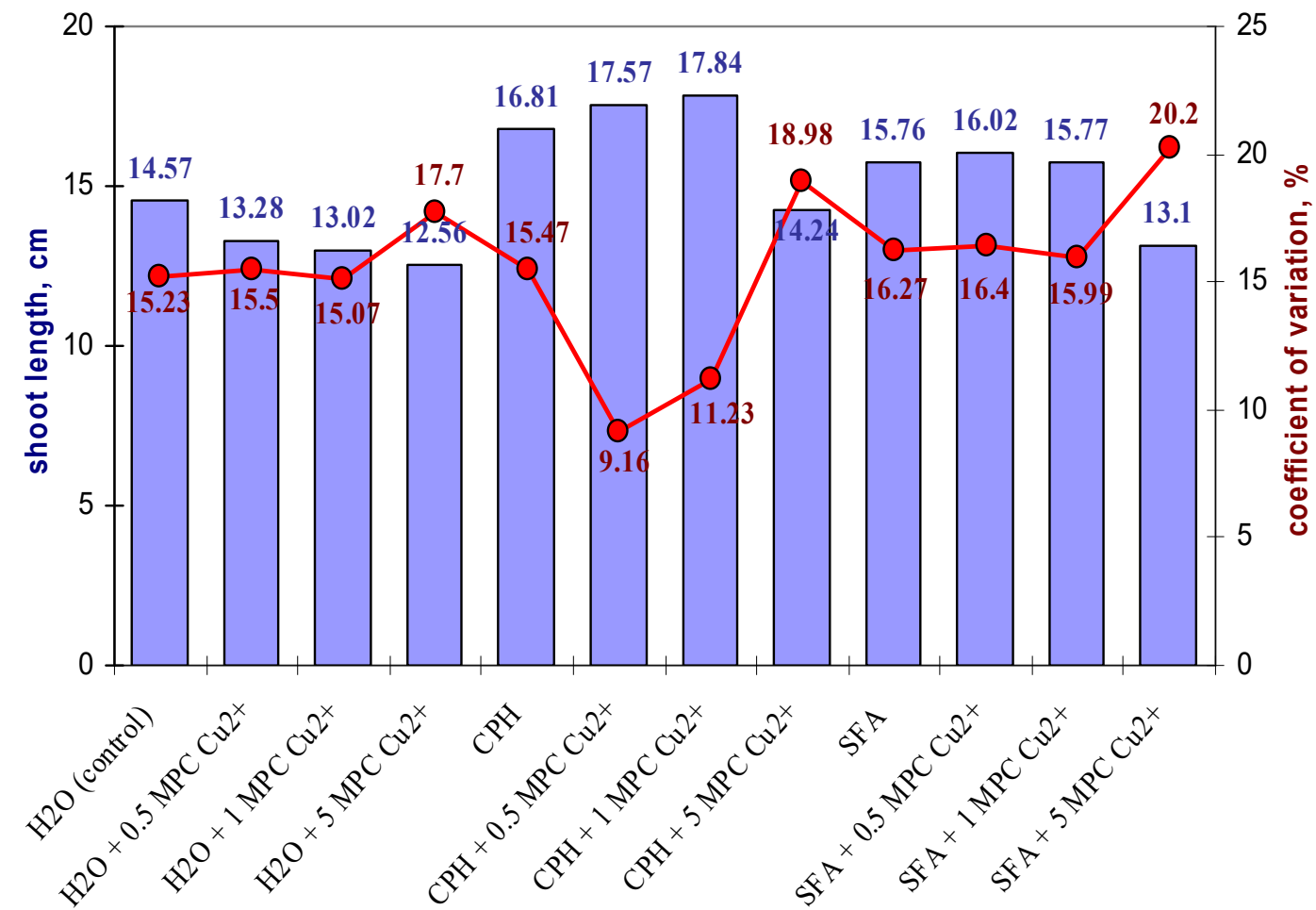
wheat.

Fig. 2. Effect of humic substances and $\mathrm{Cu}^{2+}$-ions on the length of green shoots in

It should also be noted that the coefficient of variation, which to some extent may be indicative of a changing trait (length of green shoots), in all embodiments, had mostly average values. But in those variants where the $\mathrm{Cu}^{2+}$ level was $5 \mathrm{MPC}$, its values were high - from 
$17.7 \%$ to $20.2 \%$. This is an indication that the plant is adapting to the negative influence of this factor (Fig. 2).

The roots of plants are just as important for shaping the future crop as the stem. By providing for the absorption and transportation of water and the mineral elements dissolved therein, the root system supplies all the substances necessary for the photosynthetic apparatus, from which organic substances are supplied to the roots.

The root system of wheat and other cereals consists of primary (germinal) roots, which are formed in the embryonic hypocotyl of seeds, which are in the germination stage, and stem (secondary nodular), developing from tillering nodes. The number of primary wheat roots ranges from three to six (five on average, their number depends on varietals characteristics). At the initial stages of the growing season, wheat plants take up nutrients only with their help. The intensity of the formation of secondary roots and tillering of a plant is closely related. In our experiment, the plants did not enter the tillering phase; therefore, primary roots played the main role in nutrition.

In the control variant, the average number of primary roots was $4.39 \pm 0.2$ pieces. When there were copper ions in the nutrient solution (regardless of their concentration), the number of these roots increased from $6.34 \pm 0.25$ pieces to $6.49 \pm 0.3$ pieces (the difference is statistically significant with a probability of 0.99 ). When the seeds germinated in an environment with only humic substances (SFA and $\mathrm{CPH}$ ), the number of primary roots decreased significantly - by $18 \%$ and $29.2 \%$. The addition of copper(II) sulfate solutions improved root formation. This was most active when the content of copper ions was at the level of 5 MPC. Most likely, this is due to the fact that copper ions affect enzyme systems that stimulate the formation of auxin, and it, in turn, promotes root formation [21]. Humic substances, on the contrary, possibly contribute to the synthesis of cytokinin, which inhibits the effect of auxin. As for the variability of this trait, it is mainly in the range of average values (Table 1).

Table 1

Effect of $\mathrm{Cu}^{2+}$ ions and humic substances on development wheat root system

\begin{tabular}{|c|c|c|c|c|c|c|c|c|c|}
\hline \multirow{2}{*}{ Version } & \multicolumn{3}{|c|}{$\begin{array}{l}\text { Number of primary } \\
\text { roots, pieces }\end{array}$} & \multicolumn{3}{|c|}{ Root length, cm } & \multicolumn{3}{|c|}{$\begin{array}{l}\text { The total length of all } \\
\text { roots, } \mathrm{cm}\end{array}$} \\
\hline & $\mathrm{M} \pm \mathrm{m}$ & \% & $\mathrm{t}$ & $\mathrm{N}$ & 10 & $\mathrm{t}$ & $\mathrm{M} \pm \mathrm{m}$ & $\mathrm{CV} \%$ & $\mathrm{t}$ \\
\hline $\mathrm{H}_{2} \mathrm{O}$ & & & 0 & & & 0 & $1.10=$ & 20.10 & 0 \\
\hline $\mathrm{H}_{2} \mathrm{O}+0.5 \mathrm{MPC} \mathrm{Cu}^{2+}$ & $6.36 \pm 0.25$ & 17.05 & 6.15 & $2.45=$ & 24.95 & 10.37 & $11.63 \pm 1.01$ & 29.97 & 13.42 \\
\hline $\mathrm{H}_{2} \mathrm{O}+1 \mathrm{MPC} \mathrm{Cu}^{2+}$ & $6.34 \pm 0.25$ & 16.67 & 6.09 & $2.57 \pm 0.13$ & 26.08 & 10.57 & $11.96 \pm 0.84$ & 36.80 & 13.58 \\
\hline $\mathrm{H}_{2} \mathrm{O}+5 \mathrm{MPC} \mathrm{Cu}^{2+}$ & $6.49 \pm 0.3$ & 19.34 & 5.82 & $2.37 \pm 0.18$ & 30.44 & 10.74 & $10.55 \pm 0.95$ & 37.48 & 13.93 \\
\hline $\mathrm{CPH}$ & $3.6 \pm 0.21$ & 24.19 & 2.72 & $30.71 \pm 1.54$ & 20.91 & 6.12 & $72.19 \pm 4.20$ & 24.27 & 4.83 \\
\hline $\mathrm{CPH}+0.5 \mathrm{MPC} \mathrm{Cu}{ }^{2+}$ & $4.05 \pm 0.15$ & 20.28 & 1.3 & $24.83 \pm 1.1$ & 23.38 & 3.87 & $46.87 \pm 1.40$ & 21.28 & 0.54 \\
\hline $\mathrm{CPH}+1 \mathrm{MPC} \mathrm{Cu}^{2+}$ & $5.54 \pm 0.24$ & 18.32 & 3.68 & $6.46 \pm 0.26$ & 26.48 & 7.82 & $23.6 \pm 1.44$ & 25.05 & 8.49 \\
\hline $\mathrm{CPH}+5 \mathrm{MPC} \mathrm{Cu}^{2+}$ & $6.64 \pm 0.32$ & 20.13 & 5.96 & & 36.05 & 10.45 & $12.76=$ & 37.58 & 12.78 \\
\hline SFA & $3.11 \pm 0.12$ & 21.06 & 5.49 & $27.82 \pm 1.7$ & 25.6 & 4.49 & $68.81 \pm 5.01$ & 28.27 & 3.62 \\
\hline $\mathrm{SFA}+0.5 \mathrm{MPC} \mathrm{Cu}{ }^{2+}$ & $3.55 \pm 0.19$ & 26.58 & 3.04 & $22.53 \pm 1.31$ & 29.1 & 2.41 & $33.3 \pm 2.97$ & 26.84 & 3.87 \\
\hline $\mathrm{SFA}+1 \mathrm{MPC} \mathrm{Cu}^{2+}$ & $5.4 \pm 0.22$ & 16.73 & 3.4 & $8.03 \pm 0.35$ & 28.39 & 6.67 & $29.11 \pm 1.85$ & 26.88 & 6.14 \\
\hline $\mathrm{SFA}+5 \mathrm{MPC} \mathrm{Cu}^{2+}$ & $6.38 \pm 0.27$ & 17.86 & 5.92 & $3.11 \pm 0.21$ & 30.73 & 10.2 & $14.33 \pm 1.01$ & 32.15 & 12.44 \\
\hline
\end{tabular}


The length of the root system in cereals is determined by the longest root. In contrast to the positive effect of $\mathrm{Cu}^{2+}$ ions on such an indicator as the number of primary roots, the indices - root length and total length of all roots responded negatively to the content of $\mathrm{Cu}^{2+}$ ions in the nutrient solution. In variants with $\mathrm{Cu}^{2+}$ ions without humic substances, the root length was 7.5 times smaller than the control.

When there were only humic substances in the nutrient solution, then the root length increased compared to the control by $72 \%(\mathrm{CPH})$ and by $55.8 \%$ in the version with SFA.

When the humic substances were in solution together with the heavy ions (at the level of 0.5 and $1 \mathrm{MPC}$ ), then they reduced the negative impact of this heavy metal and the root length was greater here than without the humic substances. Thus, when in the variants $\mathrm{H}_{2} \mathrm{O}+$ $0.5 \mathrm{MPC} \mathrm{Cu}^{2+}, \mathrm{H}_{2} \mathrm{O}+1 \mathrm{MPC} \mathrm{Cu}^{2+}$ the root length was $2.45 \pm 0.14 \mathrm{~cm}$ and $2.57 \pm 0.14 \mathrm{~cm}$, then in the variants with $\mathrm{CPH}-24.83 \pm 1.1 \mathrm{~cm}$ and $6.46 \pm 0.26 \mathrm{~cm}$, with SFA $-22.53 \pm 1.31$ $\mathrm{cm}$ and $8.03 \pm 0.35 \mathrm{~cm}$. Even at the concentration of $\mathrm{Cu}^{2+}$ ions at the level of $5 \mathrm{MPC}$ humic substances reduced its negative impact.

In our experiment, the plants did not form secondary roots, so we measured the total length of all primary roots that developed in them. The length of the individual roots of wheat plants in the same variant was different.

Therefore, we calculated the average of the total root length per plant. Despite the fact that in variants with $\mathrm{Cu}^{2+}$ ions without humic substances, the number of primary roots was the highest, the total length of their root system was quite small and ranged from $10.55 \pm 0.95 \mathrm{~cm}$ to $11.96 \pm 0.84 \mathrm{~cm}$ (in the control $-48.45 \pm 2.55 \mathrm{~cm}$ ). Humic substances (SFA and CPH) without $\mathrm{Cu}^{2+}$ ions had a significant positive effect on the growth of primary roots. In the variant with $\mathrm{CPH}$, the total root length was $72.19 \pm 4.2 \mathrm{~cm}$, and with SFA $68.81 \pm 5.01 \mathrm{~cm}$. In all other variants, where the humic substances were together with the $\mathrm{Cu}^{2+}$ ions, the total root length decreased, but it was still larger than without humic substances. That is, humic substances, being in a nutrient solution, reduce the toxic effect of heavy metals on the growth of primary roots in wheat.

It should also be noted that the variability of such features as the root length and the total length of all roots in most experimental variants significantly exceeded their average values. This is especially true for options where the content of copper ions was at the level of $5 \mathrm{MAC}$. In the $\mathrm{H}_{2} \mathrm{O}+5 \mathrm{MPC} \mathrm{Cu}{ }^{2+}$ variant, the coefficient of variation was $37.48 \%$, in the $\mathrm{CPH}+5 \mathrm{MPC} \mathrm{Cu}^{2+}$ variant $-37.58 \%$, in the SFA $+5 \mathrm{MPC} \mathrm{Cu}^{2+}$ variant $-32.15 \%$ (Table 1 ).

In our study, in almost all cases, the mass of green shoots largely corresponds to their length. In the experimental variants where only copper(II) sulfate was in the nutrient solution, the mass of green shoots was less than in the control. This decrease in the $\mathrm{H}_{2} \mathrm{O}+0.5 \mathrm{MPC}$ $\mathrm{Cu}^{2+}$ variant was $19.9 \%$, in the $\mathrm{H}_{2} \mathrm{O}+1 \mathrm{MPC} \mathrm{Cu}^{2+}$ variant $-8.8 \%$, and in the $\mathrm{H}_{2} \mathrm{O}+5 \mathrm{MPC}$ $\mathrm{Cu}^{2+}$ variant $-22.53 \%$. In variants where copper(II) sulfate (SFA and $\mathrm{CPH}$ ) was not included in the nutrient solution, the mass of shoots was greater than in the control.

The excess was respectively $8.2 \%$ and $5.5 \%$. When copper(II) sulfate was added to solutions of humic substances at a level of $0.5 \mathrm{MPC}$ and $1 \mathrm{MPC}$, it contributed to an even greater increase in the mass of green shoots (the excess over the control ranged from $13.2 \%$ to 19.7\%).

As for the mass of the roots, in the variants with copper sulfate (without SFA and $\mathrm{CPH})$ their mass was significantly less than in the control. In all other variants, where the composition of the nutrient solution included humic substances, the toxic effect of $\mathrm{Cu}^{2+}$ ions was slightly lower.

And only in variants where in the nutrient solution there were only humic substances the mass of roots exceeded the value in the control variant by $26.8 \%$ and $43.3 \%$. The difference is statistically significant with a probability of 0.95-0.99 (Table 2). 
Weight of green shoots and roots of wheat

\begin{tabular}{|l|l|l|l|l|l|l|}
\hline \multirow{2}{*}{ Variant } & \multicolumn{3}{|l|}{ Mass of green shoots, $\mathrm{g}$} & \multicolumn{3}{l|}{ Weight of primary roots, $\mathrm{g}$} \\
\cline { 2 - 7 } & $\mathrm{M} \pm \mathrm{m}$ & $\mathrm{CV} \%$ & $\mathrm{t}$ & $\mathrm{M} \pm \mathrm{m}$ & $\mathrm{CV} \%$ & $\mathrm{t}$ \\
\hline $\mathrm{H}_{2} \mathrm{O}($ control$)$ & $1.82 \pm 0.10$ & 12.56 & 0 & $1.27 \pm 0.10$ & 33.84 & 0 \\
\hline $\mathrm{H}_{2} \mathrm{O}+0.5 \mathrm{MPC} \mathrm{Cu}^{2+}$ & $1.47 \pm 0.08$ & 12.2 & 2.73 & $0.62 \pm 0.03$ & 7.23 & 6.23 \\
\hline $\mathrm{H}_{2} \mathrm{O}+1 \mathrm{MPC} \mathrm{Cu}^{2+}$ & $1.66 \pm 0.04$ & 7.67 & 1.49 & $0.62 \pm 0.07$ & 16.47 & 5.33 \\
\hline $\mathrm{H}_{2} \mathrm{O}+5 \mathrm{MPC} \mathrm{Cu}^{2+}$ & $1.41 \pm 0.13$ & 13.2 & 2.5 & $0.58 \pm 0.06$ & 14.44 & 5.92 \\
\hline $\mathrm{CPH}$ & $1.97 \pm 0.07$ & 9.14 & 1.23 & $1.61 \pm 0.05$ & 41.27 & 3.04 \\
\hline $\mathrm{CPH}+0.5 \mathrm{MPC} \mathrm{Cu}^{2+}$ & $2.16 \pm 0.03$ & 1.75 & 3.26 & $1.35 \pm 0.06$ & 6.42 & 0.69 \\
\hline $\mathrm{CPH}+1 \mathrm{MPC} \mathrm{Cu}^{2+}$ & $2.18 \pm 0.02$ & 1.15 & 3.53 & $0.86 \pm 0.09$ & 14.01 & 3.05 \\
\hline $\mathrm{CPH}+5 \mathrm{MPC} \mathrm{Cu}^{2+}$ & $1.76 \pm 0.05$ & 7.72 & 0.54 & $0.61 \pm 0.06$ & 14.29 & 5.66 \\
\hline $\mathrm{SFA}$ & $1.92 \pm 0.06$ & 8.78 & 0.86 & $1.82 \pm 0.02$ & 1.65 & 5.39 \\
\hline $\mathrm{SFA}+0.5 \mathrm{MPC} \mathrm{Cu}^{2+}$ & $2.13 \pm 0.09$ & 2.81 & 2.88 & $1.08 \pm 0.06$ & 14.9 & 1.63 \\
\hline $\mathrm{SFA}+1 \mathrm{MPC} \mathrm{Cu}^{2+}$ & $2.06 \pm 0.08$ & 10.45 & 1.87 & $1.07 \pm 0.05$ & 16.2 & 1.79 \\
\hline $\mathrm{SFA}+5 \mathrm{MPC} \mathrm{Cu}^{2+}$ & $1.52 \pm 0.08$ & 7.23 & 2.34 & $0.54 \pm 0.04$ & 9.26 & 6.78 \\
\hline
\end{tabular}

\section{Conclusion}

1. It was found that the presence in the nutrient solution of copper(II) sulfate at the level of $0.5,1$ and 5 maximum concentration limits contributed to an increase in the energy of germination and germination of seeds by $8.2-11.2 \%$.

2. Solutions of humic substances ( $\mathrm{CPH}$ and SFA) intensify growth processes in green shoots of wheat. Their length increased by 18.9 - 35.1\% compared with the control. Along with this, these substances inhibit the negative effect of copper sulfate even at the level of 5 MPC.

3. It is proved that aqueous solutions of copper sulfate at the levels of 1 and 5 MPC stimulate the formation of primary roots in wheat. At the same time, ions of this heavy metal have a negative effect on root growth, decreasing their length by 7.5 times compared with the control.

4. The total length of all roots in wheat plants under the influence of $\mathrm{CPH}$ and SFA exceeded the control values by $42-50 \%$. In addition, these substances significantly improved root growth in the presence of copper ions in the nutrient solution. The green mass of green shoots and roots in the studied wheat plants reacted negatively to copper ions. The humic substances improved these indices in comparison with the control by $26.8-43.3 \%$.

\section{References (in language original)}

1. Baker A. J. M. Accumulators and excluders-strategies in response of plants to heavy metals. J.of Plant Nutrition. 1981. Vol. 3. P. 643-654.

2. Yruela I. Copper in plants: acquisition, transport and interactions. Funct. Plant Biol. 2009. Vol. 36, No 5. P. 409-430.

3. Hall J. L. Cellular Mechanisms for heavy metal detoxification and tolerance. J. Experimental Botany. 2002. 53. P. 1-11.

4. Kaschl A., Chen Y. Interaction of humic substances with trace metals and their stimulatory effects on plant growth. Use of humic substances to remediate polluted enviroments from theory to practice / eds. I. V. Perminova, K. Hatfield, N. Hertkorn. Dordrecht : Springer, 2002. Vol. 52. P. 83-115.

5. Asadi M., Sedghi M., Sharifi R. S. Effects of Humic Acid on the Germination Traits of Pumpkin Seeds under Cadmium Stress. Not Sci Biol. 2013. Vol. 5, No 4. P. 480-484.

6. Stevenson F. J. Humus chemistry. Genesis, compositions, reactions. NY: Wiley and Sons, 1994. $512 \mathrm{p}$. 
7. Orlov D.S. Humic substances of soils and general theory of humification. New Delhi : Oxford \& IBH Publishing, 1995. 266 p.

8. Gomes de Melo B. A., Motta F. L., Santana M. H. A. Humic acids: Structural properties and multiple functionalities for novel technological developments. Mat. Sci. Eng. C. 2016. Vol. 62. P. 967-974.

9.

Rice J.

A., Maccarthy P. Statistical evaluation of the elemental composition of humic Substances. Org. Geochem. 1991. Vol. 17, No 5. P. 635-648.

10. Canellas L. P., Olivares F. L. Physiological responses to humic substances as plant growth promoter / Canellas and Olivares. Chem. biol. technol. agric. 2014. Vol. 1, No 3. P. 11.

11. Ali H., Akbar Y., Razaq A., Muhammad D. Effect of humic acid on root elongation and percent seed germination of wheat seeds. Intl J Agri Crop Sci. 2014. Vol. 7, No 4. P. 196-201.

12. Kiprop K., Coumon M.C., Pourtier E., Kimutai S., Kirui S. Synthesis of humic and fulvic acids and their characterization using optical spectroscopy (ATR-FTIR and UV-visible). Int. J. Appl. Sci. Technol. 2013. Vol. 3, No 8. P. 28-35.

13. Sławińska, D., Polewski, K., Rolewski, P., Sławiński J. Synthesis and properties of model humic substances derived from gallic acid. Int. Agrophys. 2007. Vol. 21. P. 199-208.

14. Litvin V.A., Minaev B.F., Baryshnikov G.V. Synthesis and properties of synthetic fulvic acid derived from hematoxylin. J. Mol. Struct. 2015. Vol. 1086. P. 25-33.

15. Eyheraguibel B., Silvestre J., Morard P. Effects of humic substances derived from organic waste enhancement on the growth and mineral nutrition of maize. Bioresour. Technol. 2008. 99. P. 4206-4212.

16. Ebrahimi M., Miri E. Effect of Humic Acid on Seed Germination and Seedling Growth of Borago officinalis and Cichorium intybus. Ecopersia. 2016. Vol. 4, No 1. P. 1239-1249.

17. Szczepanek M., Wilczewski E. Effect of humic substances on germination of wheat and barley under laboratory conditions. Acta Sci. Pol. Agric. 2011. Vol. 10, No 1. P. 79-86.

18. Спосіб одержання синтетичних фульватів : пат. 78162 Україна. № а200511458; заявл. 02.12.2005; опубл. 15.02.2007, Бюл. № 2. 2 c.

19. Bewley J.D., Bradford K.J., Hilhorst H.W.M., Nonogaki H. Seeds: physiology of development, germination and dormancy. New York : Springer, 2013. 392 p.

20. Kader M.A. A Comparison of Seed Germination Calculation Formulae and the Associated Interpretation of Resulting Data J. proc. R. Soc. New South Wales. 2005. Vol. 138. P. 65-75.

21. Singh D., Nath K., Sharma Y. K. Response of wheat seed germination and seedling growth under copper stress. J Environ Biol. 2007. Vol. 28. P. 409-14.

\section{References}

1. Baker, A. J. M. (1981). Accumulators and excluders-strategies in response of plants to heavy metals. J.of Plant Nutrition. Vol. 3, 643-654.

2. Yruela, I. (2009). Copper in plants: acquisition, transport and interactions. Funct. Plant Biol. Vol. 36, No 5, 409-430.

3. Hall, J. L. (2002). Cellular Mechanisms for heavy metal detoxification and tolerance. J. Experimental Botany. 53, 1-11.

4. Kaschl, A., Chen, Y. (2002). Interaction of humic substances with trace metals and their stimulatory effects on plant growth. Use of humic substances to remediate polluted enviroments from theory to practice / eds. I. V. Perminova, K. Hatfield, N. Hertkorn. Dordrecht : Springer,. Vol. 52, 83-115.

5. Asadi, M., Sedghi, M., Sharifi, R. S. (2013). Effects of Humic Acid on the Germination Traits of Pumpkin Seeds under Cadmium Stress. Not Sci Biol. Vol. 5, No 4, 480-484.

6. Stevenson, F. J. (1994). Humus chemistry. Genesis, compositions, reactions. NY: Wiley and Sons. 512.

7. Orlov, D. S. (1995). Humic substances of soils and general theory of humification. New Delhi : Oxford \& IBH Publishing, 266.

8. Gomes, de Melo B. A., Motta, F. L., Santana, M. H. A. (2016). Humic acids: Structural properties and multiple functionalities for novel technological developments. Mat. Sci. Eng. C. Vol. 62, 967-974.

9.Rice, J. A., Maccarthy, P. (1991). Statistical evaluation of the elemental composition of humic Substances. Org. Geochem. Vol. 17, No 5, 635-648.

9. Canellas, L. P., Olivares, F. L. (2014). Physiological responses to humic substances as plant growth promoter / Canellas and Olivares. Chem. biol. technol. agric. Vol. 1, No 3, 11.

10. Ali, H., Akbar, Y., Razaq, A., Muhammad, D. (2014). Effect of humic acid on root elongation and percent seed germination of wheat seeds. Intl J Agri Crop Sci. Vol. 7, No 4, 196-201.

11. Kiprop, K., Coumon, M.C., Pourtier, E., Kimutai, S., Kirui, S. (2013). Synthesis of humic and fulvic acids and their characterization using optical spectroscopy (ATR-FTIR and UV-visible). Int. J. Appl. Sci. Technol. Vol. 3, No 8, 28-35.

12. Sławińska, D., Polewski, K., Rolewski, P., Sławiński J. (2007). Synthesis and properties of model 
humic substances derived from gallic acid. Int. Agrophys. Vol. 21, 199-208.

13. Litvin, V.A., Minaev, B.F., Baryshnikov, G.V. (2015). Synthesis and properties of synthetic fulvic acid derived from hematoxylin. J. Mol. Struct. Vol. 1086, 25-33.

14. Eyheraguibel, B., Silvestre, J., Morard, P. (2008). Effects of humic substances derived from organic waste enhancement on the growth and mineral nutrition of maize. Bioresour. Technol. 99, 4206-4212.

15. Ebrahimi, M., Miri, E. (2016). Effect of Humic Acid on Seed Germination and Seedling Growth of Borago officinalis and Cichorium intybus. Ecopersia. Vol. 4, No 1, 1239-1249.

16. Szczepanek, M., Wilczewski, E. (2011). Effect of humic substances on germination of wheat and barley under laboratory conditions. Acta Sci. Pol. Agric. Vol. 10, No 1, 79-86.

17. Sposib oderzhannia syntetychnykh fulvativ [The method of preparing synthetic fulvates]: pat. 78162 Ukraine. № a200511458; stated. 02.12.2005; publ. 15.02.2007, Bul. № 2. (in Ukr.)

18. Bewley, J.D., Bradford, K.J., Hilhorst, H.W.M., Nonogaki, H. (2013). Seeds: physiology of development, germination and dormancy. New York : Springer. 392.

19. Kader, M.A. (2005). A Comparison of Seed Germination Calculation Formulae and the Associated Interpretation of Resulting Data J. proc. R. Soc. New South Wales. Vol. 138, 65-75.

20. Singh, D., Nath, K., Sharma, Y. K. (2007). Response of wheat seed germination and seedling growth under copper stress. J Environ Biol. Vol. 28, 409-14.

\section{Литвин В.А., Дерій С.І., Плахотнюк Л.М., Нйо Р.А. Вплив гумінових речовин на проростання насіння пиениці під впливом важких металів.}

Постановка проблеми. Бурхливий розвиток промисловості в останні десятиліття став причиною глобального забруднення навколишнього середовища, в тому числі важкими металами. Особливу небезпеку становить накопичення важких металів в рослинах, широко вирощуваних в практиці рослинництва, таких як пшениця. Серед ростостимулюючих $i$ ремедіачійних препаратів особливої уваги заслуговують сполуки природного походження гумінові речовини. В даний час в усьому світі спостерігається підвищений інтерес до гумінових речовин, удосконалюються технології їх виробництва, розширюється сировинна база, до якої залучаються нові види сировини. Особливий інтерес представляють синтетичні гумінові речовини, отримані з низькомолекулярних фенольних попередників. Строгий контроль умов синтезу дозволяє отримувати продукт зі стандартизованими властивостями, щуо є одним з переваг над природними гуміновими речовинами. Крім того, передбачається, що природа низькомолекулярного фенольного попередника впливає на біологічну активність кінцевого продукту.

Метою нашого дослідження було вивчення впливу гумінових речовин різного походження (комплексного препарату природних гумінових речовин та синтетичних фульвокислот з пірокатехіну) на проростання та морфологічні характеристики пшенииі за умов впливу важких металів $\left(\mathrm{Cu}^{2+}\right)$.

Методи дослідження. При проведенні дослідження було використано лабораторний, обліковий, аналітичний та математично-статистичний методи.

Результати. Порівняльне дослідження впливу комплексного препарату природних гумінових речовин та синтетичних фульвокислот з пірокатехіну на схожість насіння пшениці свідчить про стимулюючу їх дію в порівнянні з контролем на 11.2\% та 8.2 \% відповідно. Наявність в живильному розчині йонів С. ${ }^{2+}$ на рівні 0.5, 1 та 5 ГДК сприяла підвищенню енергії проростання та схожості насіння у всіх дослідах. Досліджувані типи гумінових речовин інтенсифікують ростові процеси у зелених пагонах пшениці. У порівнянні з контролем їх довжина збільшувалась на 18.9 - 35.1\%. Поряд з циим цүі речовини інгібують негативний вплив $\mathrm{Cu}^{2+}$ іони навіть на рівні 5 ГДК. Встановлено, що водні розчини $\mathrm{Cu}^{2+}$ іонів стимулюють утворення первинних коренів у пшениці. В той же час йони изьго важкого металу чинять негативний вплив на ріст коренів, зменшуючи їх довжину в порівнянні з контролем у 7.5 рази. Загальна довжина всіх коренів у рослин пшениці під дією різних типів гумінових речовин перевищувала контрольні значення на 42 - 50 \%. Поряд з цим иі речовини значно покращували ріст коренів при наявності в живильному розчині $\mathrm{Cu}^{2+}$ іонів. Наявність $\mathrm{Cu}^{2+}$ йонів у розчині негативно вплинула на сиру масу зелених пагонів та коренів у досліджуваних рослин пшениці. Однак, гумусові речовини покрамували иі показники у порівнянні з контролем на $26.8-43.3 \%$, щзо свідчить про їх детоксикуючу дію. 
Висновки. Таким чином, обробка насіння пшениці досліджуваними препаратами природних гумінових речовин і синтетичних фульвокислот з пірокатехіну активізує біологічні $i$ фізіологічні прочеси в насінні, тим самим впливає на життєдіяльність рослини вже на початковому етапі розвитку, впливає на утворення додаткових первинних корінців $i$ ріст проростків пшениці. Досліджувані препарати позитивно впливають і на накопичення сирої маси проростків пшениці, дозволяють отримати дружні і рівномірні сходи. Крім того, в умовах забруднення грунтів $\mathrm{Cu}^{2+}$ іонами різні типи гумінових препаратів проявляють фітопротекторні властивості.

Ключові слова: гумінові речовини, синтетичні фульвокислоти, важкі метали, пшениця, енергія проростання, морфологічні характеристики.

Одержано редакцією

Прийнято до публікації
18.03.2019

11.06 .2020 